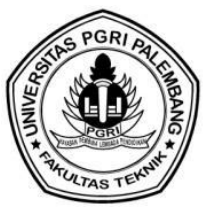

\title{
PENGARUH PARALEL PENTANAHAN TRANSFORMATOR DAN PENTANAHAN ARRESTER TERHADAP KINERJA RESISTANSI PENTANAHAN TRANSFORMATOR DISTRIBUSI 250 KVA GARDU BA 005 di PT. PLN (PERSERO) UP3 BENGKULU ULP TELUK SEGARA
}

\author{
Pebi Muhammad Rizki ${ }^{1}$, Dian Eka Putra ${ }^{2}$ \\ ${ }^{1,2}$ Program Studi Teknik Elektro Fakultas Teknik Universitas Palembang \\ pebimrizki@gmail.com ${ }^{1}$,dianekaputra@gmail.com
}

\begin{abstract}
ABSTRAK Sistem Pentanahan pada gardu transformator distrbusi sangatlah penting untuk kehandalan suplai energi listrik serta melindungi manusia dan peralatan dari tegangan lebih atau arus bocor, selain itu sistem pentanhan terutaman pentanhan netral yang baik akan menghasilkan tegangan yang sempurna. Untuk melindungi manusia serta perangakat gardu distribusi BA 003 Transformator Distribusi 250 KVA dari tegangan sentuh terutama pada musim kemarau, cuaca cerah dan beban puncak penggunaan Transformator 250 KVA diperlukan paralel grounding Arrester dan Grounding Bodi atau cangkang Transformator. Dari hasil pengukuran Beban puncak terjadi pada malam hari dengan pembebanan mencapai 54\% dari kapasitas transformator distribusi $250 \mathrm{KVA}$ sebesar $194 \mathrm{KVA}$. Untuk pengukuran Resistansi terbesar pada pentanahan Arrester Transformator sebesar 8,1 $\Omega$ tejadi pada pukul $14.00-$ 15.00 Wib, Resistansi terbesar pada pentanahan Bodi atau Cangkang Transformator sebesar 8,3 $\Omega$ terjadi pada pukul 14.00 - 15.00 Wib. Dari pengukuran Paralel Instalasi pentanahan Arrester Transformator dan Bodi atau Cangkang Transformator sebesar 7,7 $\Omega$ pada pukul 14.00 - $15.00 \mathrm{Wib}$, dengan kondisi cuaca pada siang hari Cerah.
\end{abstract}

Kata Kunci : Pentanhan, Gardu Distribusi, Transformator, Arrester.

\begin{abstract}
ABSTRAC The grounding system in the distribution transformer substation is very important for the reliability of the supply of electrical energy and protects humans and equipment from overvoltages or leakage currents, besides that the mainly good neutral grounding system will produce the perfect voltage. To protect humans and distribution substation equipment BA 003 Distribution Transformer 250 KVA from touch voltage, especially in the dry season, sunny weather and peak loads using a $250 \mathrm{KVA}$ Transformer requires parallel grounding Arrester and Grounding Body or Transformer shell. From the measurement results, the peak load occurs at night with the loading reaching $54 \%$ of the $250 \mathrm{KVA}$ distribution transformer capacity of 194 KVA. For the measurement of the largest resistance on the grounding of the Transformer Arrester of $8.1 \Omega$, occurs at 14.00 - $15.00 \mathrm{WIB}$, the greatest resistance on the grounding of the Transformer Body or Shell of $8.3 \Omega$ occurs at $14.00-15.00$ WIB. From the parallel measurement of the grounding installation of the Transformer Arrester and the Transformer Body or Shell of $7.7 \Omega$ at 14.00 - 15.00 WIB, with sunny weather conditions during the day.
\end{abstract}

Keywords: grounding, Distribution Substation, Transformer, Arrester.

\section{PENDAHULUAN}

Gardu Distribusi merupakan suatu perangkat yang berperan penting dalam menunjang penyaluran energi listrik tegangan rendah ke konsumen, dikarenkan sebagian banyak pelanggan listrik yaitu pelanggan tegangan rendah. Dalam kegiatan operasional di PT. PLN (Persero) Gardu Distribusi hendaklah aman dari arus bocor dan tegangan sentuh. Dimana pengetahanan peralatan yang bertujuan mengentanahkan bagian dari peralatan yang pada kerja normal tidak dialiri arus (Hutahuruk, 1999). Guna menjaga kehandalan dari Gardu Distribusi Tegangan Rendah tersebut maka diperlukan suatu pentanahan yang baik guna untuk memperoleh tegangan potensial yang merata dalam suatu bagian struktur dan peralatan, serta untuk memperoleh jalan balik arus hubungsingkat/arus gangguan ke tanah yang memiliki resistansi rendah. Sebab apabila arus gangguan dipaksakan mengalir ke tanah dengan tahanan yang tinggi, maka hal tersebut akan menimbulkan perbedaan tegangan yang besar sehingga dapat membahayakan. Kecelakaan pada personil, timbul 
pada saat hubung singkat ketanah terjadi (Daryanto, 2012). Untuk nilai resistansi tanah PT. PLN (Persero) sesuai dengan SPLN 1978 dengan nilai resistansi maksimal 5 Ohm (PLN, 1978), sehingga perlu dilakukan pemeliharaan rutin untuk sistem pentanahan guna menjaga nilai resistansi yang sesuai standar dan menjaga kehandalan suatu peralatan itu sendiri. Selain itu disaat terjadinya kemarau atau musim penggering akan menaikan suhu tanah dan mengurangi kelembaban tanah, maka untuk mempertahankan nilai resistansi tersebut diperlukan percobaan pengkombinasikan secara paralel antara instalasi pentanahan transformator distribusi $250 \mathrm{KVA}$ dengan Instalasi pentanahan Arrester pada Gardu distribusi BA 005 di PT. PLN (Persero) UP3 Bengkulu ULP Teluk Segara

\section{TINJAUAN PUSTAKA}

\section{Fungsi Pentanahan}

Konstruksi dari elektroda bergantung dari kode daerah yang dipergunakan. Fungsinya untuk mengadakan sebuah resistansi yang rendah sebagai jalan menuju ke massa tanah. Elektroda pentanahan dapat dilakukan dengan memakai konduktor yang pada dasarnya untuk kontak/penghubung dengan tanah. Akhir dari pemasangan nantinya, sambungan elektroda pentanahan harus terpasang dengan kuat, agar fungsi yang diharapkan dapat tercapai. Elektroda pentanahan adalah tahanan antara suatu titik yang dihubungkan ke bumi dan remote earth. Remote earth itu adalah suatu titik yang jauh dari elektroda pentanahan dimana tahanan elektroda pentanahan tidak naik ketika jarak dinaikkan.

\section{Macam Pentanahan}

Sistem pentanahan dapat dibedakan menjadi (Hutahuruk, 1999), yaitu :

1. Pentanahan sistem

2. Pentanahan penangkal petir

3. Pentanahan peralatan

\section{Pentanahan Sistem}

Salah satu factor kunci dalam setiap usaha Pengaman (perlindungan) rangkaian listrik adalah pentanahan (AS Pabla, 2019) (Dian Eka Putra J. U., 2018). Pentanahan sitem dimana pentanahan dari titik yang merupakan bagian dari jaringan listrik, misalnya titik netral generator, titik netral transformator atau titik pada hantaran tengah atau hantaran netral. Suatu gangguan pentanahan pada salah satu bagian sistem harus dapat diisolir dan diamankan tanpa mematikan atau menggangu keseluruhan sistem, sehingga keandalan dan kontinuinitas pelayanan kepada pengguna energi listrik ini (konsumen) dapat dijamin. Dengan dipasangnya peralatan pentanahan sistem ini diharapkan gangguan dapat dibatasi pada grup sistem yang mengalami gangguan saja.

\section{Pentanahan Peralatan Sistem Grid}

Pentanahan ini adalah sistem pentanahan dengan menggunakan batang-batang elektroda yang ditanamkan sejajar dipermukaan tanah, batang batang ini terhubung satu sama lain, bertujuan untuk meratakan tegangan yang mungkin timbul. Dengan cara ini bila jumlah elektroda yang ditanam banyak, maka bentuknya mendekati bentuk plat dan ini merupakan bentuk maksimum atau bentuk yang mempunyai harga tahanan yang paling kecil untuk daerah tertentu. tetapi bentuk ini mahal dilakukan oleh karena itu perlu dicari bentuk yang sederhana dan murah tetapi mempunyai harga tahanan yang memenuhi persyaratan. 


\section{Pentanahan Peralatan sistem Rod}

Pentanahan ini adalah pentanahan yang menggunakan batang elektroda yang ditanamkan secara tegak lurus kedalam tanah, fungsinya hanya untuk mengurangi atau memperkecil tahanan pentanahan.

Bila dilakukan paralel elektroda yang lebih banyak, maka tahanan pentanahan akan lebih kecil. Penanaman batang elektroda ini kedalam tanah dapat berbentuk bujur sangkar atau persegi panjang dengan jarak antara elektroda sama. sedangkan konduktor penghubung elektroda terletak diatas permukaan tanah sehingga tidak diperhitungkan tahanannya.

\section{Pentanahan Arrester}

Pentingnya fungsi arrester dalam sistem kooardinasi isolasi pada instalasi tenaga listrik, maka pemasangan alat ini harus betul-betul memenuhi persyaratan teknis. Dalam prakteknya kebanyakan arrester dilakukan dengan pentanahan local, yaitu Rods yang dimasukan ketanah dekat dengan arrester. Selanjutnya dari terminal pentanahan arrester dihubungkan ke rods dengan menggunakan konduktor, besarnya tahanan dibuat sekecil mungkin dan harganya dibatasi dibawah $5 \Omega$ (Samaulah, 2004). Arrester yang sering dipakai berjenis Explulsion Type Lightning Arrester sebagai tabung pelindung untuk peralatan listrik yang berfungsi memotong petir (Reynaldo Zoro, 2018).

\section{Pentanahan Peralatan}

Pentanahan peralatan, berlainan dengan pentanahan sistem, adalah pentanahan bagian dari peralatan yang pada kerja normal tidak dilalui arus (Hutahuruk, 1999). Tujuan dari pentanahan peralatan tersebut adalah :

a. Untuk membatasi tegangan antara bagian-bagian peralatan yang tidak dilalui arus dan antara bagian-bagian ini dengan tanah sampai pada suatu harga yang aman (tidak membahayakan) untuk semua kondisi operasi normal atau tidak normal. Untuk mencapai tujuan ini,suatu sistem pentanahan peralatan sangat dibutuhkan. Sistem pentanahan ini gunanya untuk memperoleh pontensial yang merata dalam semua bagian struktur dan peralatan,dan juga agar operator atau orang yang berada di daerah instalasi itu berada pada potensial yang sama dan tidak berbahaya pada setiap waktu.

b. Untuk memperoleh impedansi yang kecil/rendah dari jalan balik arus hubung singkat ketanah. kecelakaan pada personil pada saat hubung singkat ketanah terjadi, jadi bila arus hubung singkat ini dipaksakan mengalir ketanah melalui impedansi yang tinggi, ini akan menimbulkan pebedaan potensial yang besar dan sangat berbahaya

\section{Elektroda Pentanahan}

Elektroda pentanahan adalah suatu penghantar yang ditanamkan kedalam tanah dan membuat kontak langsung dengan tanah. Adanya kontak langsung ini dengan tujuan agar diperoleh pelaluan arus yang sebaik-baiknya apabila terjadi gangguan sehingga arus tersebut disalurkan ke tanah. Bahan konduktor merupakan bahan yang digunakan sebagai elektroda pentanahan, berdasarkan ketentuan maka bahan tersebut adalah besi, aluminium, dan tembaga. Dari ketiga jenis bahan tersebut ditinjau dari sifat mekanis, elektris dan kimiawi maka tembaga mempunyai keunggulan yang lebih tinggi dibandingkan dengan bahan yang lain namun ditinjau dari segi biaya tembaga cenderung lebih mahal, tetapi mengingat kesulitan yang timbul bila elektroda tersebut mengalami kerusakan baik pengaruh elektris, mekanis dan kimiawi maka tembaga lebih unggul (Sunarno, 2006). 


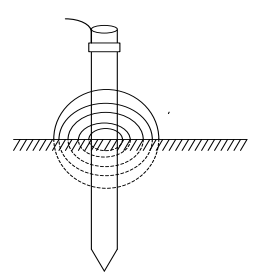

Gambar 1. Komponen Tahanan dari suatu batang elektroda pentanahan

Untuk mendapatkan tahanan pembumian yang kecil,diperlukan elektroda pentanahan. Prinsip dasar untuk memperoleh tahanan yang kecil adalah dengan membuat permukaan elektroda bersentuhan dengan tanah sebesar mungkin, sesuai dengan rumus :

$$
R=\frac{\rho L}{A}
$$

Dimana :

$\mathrm{R}=$ Tahanan Pentanahan $(\Omega)$

$\rho=$ Tahanan Jenis Tanah $(\Omega \mathrm{m})$

$\mathrm{L}=$ Panjang lintasan arus pada tanah $(\mathrm{m})$

$\mathrm{A}=$ Luaspenampang lintasan arus pada tanah $\left(\mathrm{m}^{2}\right)$

\section{Elektroda bentuk Batang ( Rod )}

Elektroda bentuk batang ini adalah elektroda bentuk pipa atau batang profil yang ditanamkan tegak lurus kedalam tanah dengan kedalaman antara 1 sampai 10 meter.

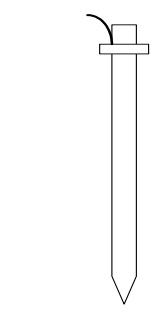

Elektroda batang Tunggal

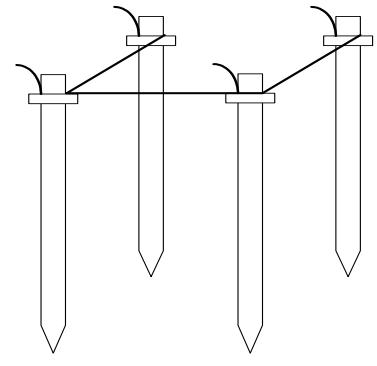

Elektroda batang dalam group ( mesh

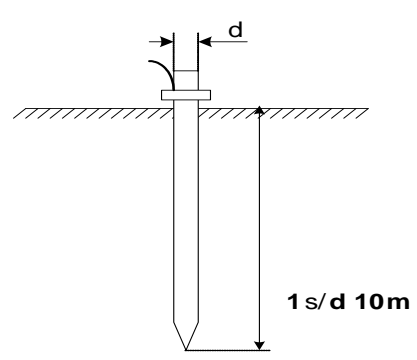

Gambar 2. Bentuk-bentuk Elektroda Batang

Dibawah ini diperlihatkan distribusi tegangan yang terjadi pada elektroda pada saat terjadi gangguan.

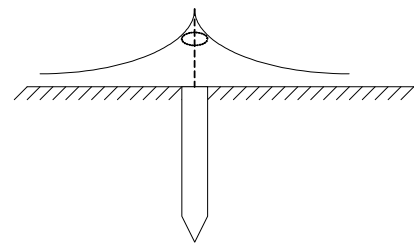

Distribusi tegangan sekitar Satu batang elektroda

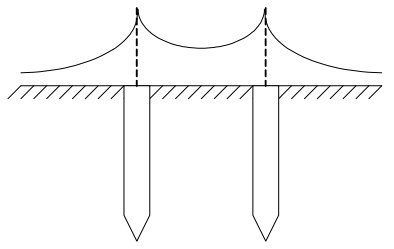

Distribusi tegangan sekitar dua batang elektroda

Gambar 3. Distribusi tegangan sekitar Elektroda 
Dengan demikian untuk jumlah elektroda yang lebih banyak yang ditanam tegak lurus kedalam tanah maka tahanan pentanahannya semakin kecil dan distribusi tegangan akan lebih merata.

\section{Satu Buah Elektroda Batang Ditanam Vertikal Ke Dalam Tanah}

Dasar perhitungan tahanan pentanahan adalah perhitungan kapasitansi dari susunan batangbatang elektroda pentanahan dengan anggapan bahwa distribusi arus atau muatan uniform sepanjang batang elektroda. Hubungan tahanan dan kapasitansi dapat dijelaskan dengan suatu analogi. Analogi ini merupakan dasar perhitungan karena aliran arus masuk ke dalam tanah dari elektroda pentanahan mempunyai kesamaan dengan emisi fluks listrik dari konfigurasi yang sama dari konduktor yang mempunyai muatan yang terisolir (Dian Eka Putra F. A., 2018).

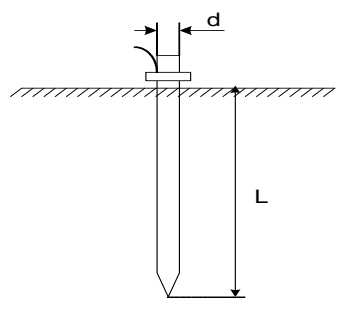

Gambar 4. Elektroda batang ditanamkan tegak lurus

\section{Dua Buah Elektroda Batang Ditanam Vertikal Ke Dalam Tanah}

$$
\begin{aligned}
& R_{b t} 2=\frac{\rho}{4 \pi L}\left(\ln \frac{4 L}{d}-1\right)+\frac{\rho}{4 \pi s}\left(1-\frac{L^{2}}{3 s^{2}}+\frac{2 L^{4}}{5 s^{4}}\right) \text { Untuk s }>\mathrm{L} \\
& R_{b t} 2=\frac{\rho}{4 \pi L}\left(\ln \frac{4 L}{d}+\ln \frac{4 L}{s}-2+\frac{s}{2 L}-\frac{s^{2}}{16 L^{2}}+\frac{s^{4}}{512 L^{4}}\right) \text { Untuk s }<\mathrm{L}
\end{aligned}
$$

Dimana $\mathrm{s}=$ Jarak antara kedua elektroda batang ( meter )

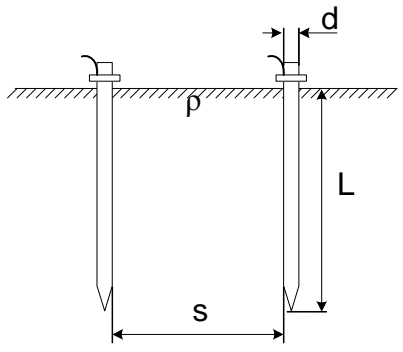

Gambar 5. Dua batang elektroda ditanamkan tegak lurus

\section{Tahanan Jenis Tanah}

Tahanan jenis tanah direpresentasikan dengan notasi $\rho$. Pembumian itu sendiri merupakan sebuah badan yang sangat besar dapat digambarkan sebagai sebuah bak penampung yang tidak terbatas untuk mengalirkan arus ke dalam tanah dan dapat mempertimbangkan tahanan yang kecil untuk mengalirkan arus.

Harga tahanan jenis tanah pada daerah kedalaman yang terbatas tergantung pada beberapa faktor yaitu :

a. Keadaan struktur tanah antaralain struktur geologi seperti tanah liat, tanah rawa,tanah berbatu,tanah pasir, tanah gambut dan sebagainya.

b. Unsur kimia yang terkandung dalam tanah, seperti garam,logam,dan mineral lainnya.

c. keadaan iklim, basah atau kering. 
d. Temperatur tanah dan jenis tanah

Tabel 1 Harga Tahanan Jenis Tanah (PUIL2000, 2000)

\begin{tabular}{|l|c|}
\hline \multicolumn{1}{|c|}{ Jenis Tanah } & $\begin{array}{c}\text { Resistansi Jenis Tanah } \\
(\mathbf{\Omega . m})\end{array}$ \\
\hline Tanah Rawa & $10-40$ \\
\hline $\begin{array}{l}\text { Tanah Liat dan Tanah } \\
\text { Ladang }\end{array}$ & $20-100$ \\
\hline Pasir Basah & $50-200$ \\
\hline Kerikil Basah & $200-3000$ \\
\hline Pasir / kerikil kering & $<10000$ \\
\hline Tanah berbatu & $2000-3000$ \\
\hline Air laut dan air tawar & $10-100$ \\
\hline
\end{tabular}

\section{METODE PENELITIAN}

Tahapan-tahapan penelitian yang akan dilakukan sebagai berikut :

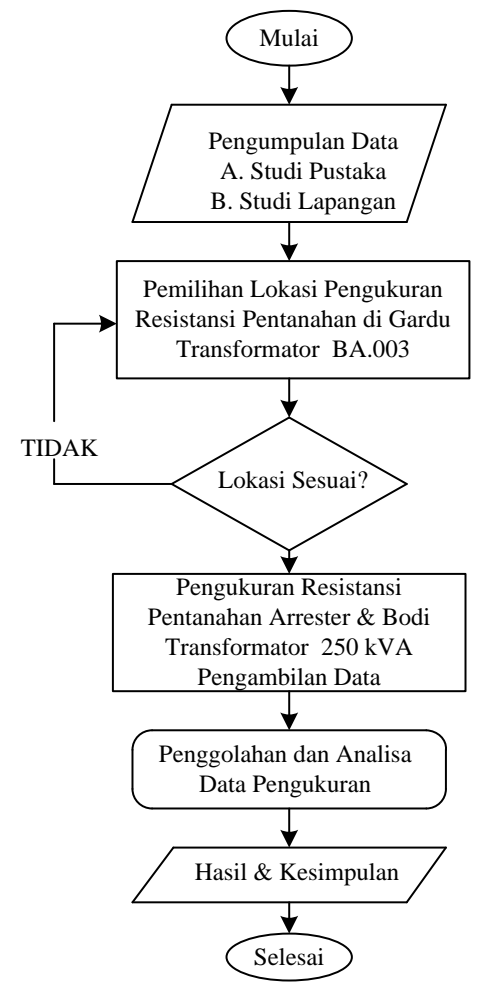

Gambar 6. Tahapan Penelitian

Penelitian Pengaruh Paralel Grounding Transformator Dan Grounding Arrester Terhadap Kinerja Resistansi Pentanahan Transformator Distribusi 250 KVA Gardu BA 005 di PT. PLN (Persero) UP3 Bengkulu ULP Teluk Segarad dilakukan dengan metode eksprimental dengan langkah-langkah :

1. Pengumpulan data-data mengenai penelitian dan pengukuran.

2. Surve lokasi penelitian dan pengukuran Resistansi Grounding di lokasi Pada Gardu BA 005 Transformator Distribusi 250 KVA PT. PLN (Persero) UP3 Bengkulu ULP Teluk Segara.

3. Peralatan dan Alat Ukur Resistansi Penranahan yaitu Digital Earth Tester (Kyoritsu 4105A) dan Tools Set 
4. Peralatan Pengaman atau Alat Pelindung Diri dan Prosedur K3 Pengukuran Resistansi pentabnahan selama proses pengukuran lapangan.

5. Penentuan Titik sentris tempat alat ukur elektrode Earth Tester dipasang. Metode pengukuran tahanan menggunakan metode tiga titik, dimana 1 batang elektrode memiliki 2 buah titik atau elektrode pasak bantu.

\section{PEMBAHASAN}

Mengacu pada SPLN 1978 dan PUIL 2000 untuk pentanahan sebaiknya di bawah 5 Ohm, semakin rendah nilai resistansi pentanahan akan semakin bagus dan handal dari bahaya terkontak langsung terhadap arus bocor atau tegangan sentuh.

\section{Perhitungan Tahanan Pentanahan}

Untuk perehitungan Resistansi Pentanahan dua batang elektro yang diparalel dengan menggunakan persamaan 2.4. yaitu :

$$
R=\frac{\rho}{4 . \pi \cdot \mathrm{L}} x\left(\ln \frac{4 L}{a}+\ln \frac{4 L}{s}-2+\frac{s}{2 L}-\frac{s^{2}}{16 L^{2}}+\frac{s^{4}}{512 L^{4}}\right)
$$

Untuk $\mathrm{S}<\mathrm{L}$ Dimana : perhitungan tahanan pentanahan

- Perhitungan tahanan pentanahan untuk duabatangelektroda yang diparalel

Dari data hasil survey lapangan pada Gardu Distribusi BA. 005 Transformator 250 KVA didapat variable sebagai berikut :

$$
\begin{array}{ll}
\mathrm{P} & : 100 \Omega \mathrm{cm} \\
a & : 0,35 \mathrm{~cm} \\
\pi & : 3,14 \\
\mathrm{~L} & : 250 \mathrm{~cm} \\
\mathrm{~s} & : 100 \mathrm{~cm}
\end{array}
$$

Dari data atau variable diatas, Dengan menggunakan persamaan 2.3 perhitungan dua batang elektroda yang diparalel didapat sebesar $0,122 \Omega$.

\section{ANALISA}

Berdasarkan pengukuran yang Dilakukan salama 5 hari Pada Trafo 250 kVA Gardu BA 0003 PT. PLN (Persero) UP3 Bengkulu ULP Teluk Segara hasil yang di dapatkan :

1. Pengukuran Resistansi Pentanahan Pukul 09.00-10.00 WIB

Tabel 2. Pengukuran Resistansi Pentanahan pada Pukul 09.00 - 10.00 Wib

\begin{tabular}{|c|c|c|c|c|c|c|}
\hline No & Tanggal & $\begin{array}{c}\text { Pembebanan } \\
\text { Transformator }\end{array}$ & Cuaca & $\begin{array}{c}\text { Nilai } \\
\text { Grounding } \\
\text { Arrester } \\
\text { Transformator }\end{array}$ & $\begin{array}{c}\text { Nilai Grounding } \\
\text { Body } \\
\text { Transformator }\end{array}$ & $\begin{array}{c}\text { Nilai } \\
\text { Grounding } \\
\text { Diparalel }\end{array}$ \\
\hline 1 & 21 Mei 2020 & $37 \%$ & Cerah & 3,3 & 2,8 & 2,7 \\
\hline 2 & 22 Mei 2020 & $49 \%$ & Berawan & 2,3 & 2,2 & 2 \\
\hline 3 & 23 Mei 2020 & $41 \%$ & Cerah & 3,1 & 2,5 & 2,1 \\
\hline 4 & 25 Mei 2020 & $38 \%$ & Cerah & 2,5 & 2,9 & 2,7 \\
\hline 5 & 26 Mei 2020 & $30 \%$ & Berawan & 1,6 & 1,8 & 1,4 \\
\hline
\end{tabular}




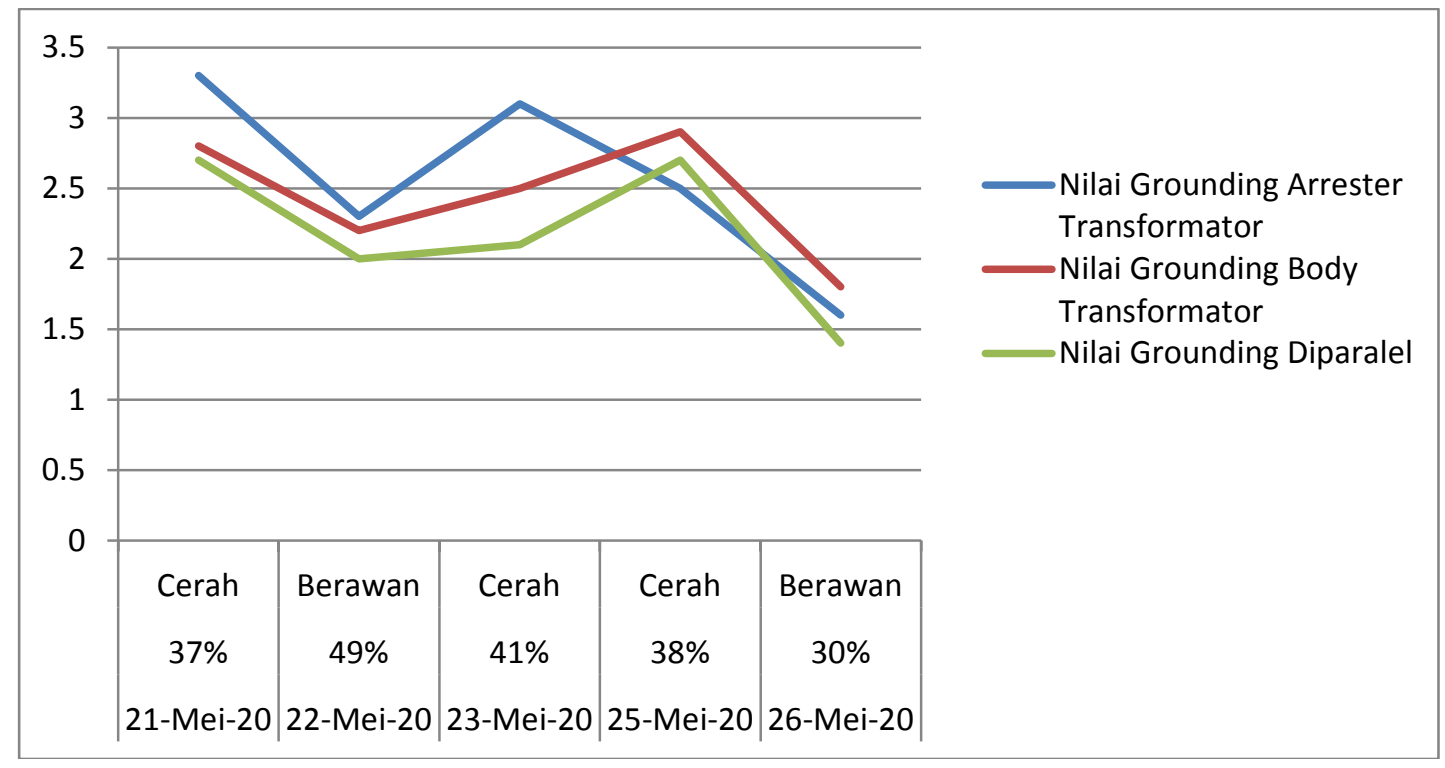

Gambar 7. GrafikPengukuran Resistansi Pentanahan pada Pukul 09.00 - 10.00 Wib

Dilihat dari gambar 7. Grafik Pengukuran yang dilakukan pada tanggal 21 Mei 2020 yang dimulai pukul 09.00 sampai dengan pukul $10.00 \mathrm{Wib}$ dapat dilihat pada Tabel 2, menunjukan resistansi tertinggi pada masing-masing pentanahan dimana pada pentanahan Arrester untuk Transformator sebesar 3,3 $\Omega$ di tanggal 21 mei 2020 dan pada pentanahan Body Transformator sebesar 2,9 $\Omega$ di tanggal 25 Mei 2020, dengan keadaan cuaca cerah. Pada pengukuran paralel anatara Grounding Arrester dan Grounding Bodi Transformator nilai resistansi pentanahan tertinggi yaitu 2,7 $\Omega$ pada tanggal 21 dan 25 Mei 2020. Dilihat dari keadaan cuaca naiknya nilai resistansi pentanahan dipengaruhi oleh keadaan suhu dan kondisi cuaca. Sehingga nilai resistansi pengukuran pentanahan dilapangan lebih besar dari nilai resitansi pentanahan yang didapat dari perhitungan sebesar $0,122 \Omega$.

2. Pengukuran Resistansi Pentanahan Pukul 14.00 -15.00 WIB

Tabel 3. Pengukuran Resistansi Pentanhan pada Pukul 14.00 - 15.00 Wib

\begin{tabular}{|c|c|c|c|c|c|c|}
\hline No & Tanggal & $\begin{array}{c}\text { Pembebanan } \\
\text { Transformator }\end{array}$ & Cuaca & $\begin{array}{c}\text { Nilai } \\
\text { Grounding } \\
\text { Arrester } \\
\text { Transformator }\end{array}$ & $\begin{array}{c}\text { Nilai Grounding } \\
\text { Body } \\
\text { Transformator }\end{array}$ & $\begin{array}{c}\text { Nilai } \\
\text { Grounding } \\
\text { Diparalel }\end{array}$ \\
\hline 1 & 21 Mei 2020 & $45 \%$ & Cerah & 8,1 & 8,3 & 7,7 \\
\hline 2 & 22 Mei 2020 & $49 \%$ & Berawan & 1,5 & 1,6 & 2 \\
\hline 3 & 23 Mei 2020 & $43 \%$ & Cerah & 3,4 & 2,2 & 3,7 \\
\hline 4 & 25 Mei 2020 & $41 \%$ & Cerah & 6,5 & 4,9 & 1,4 \\
\hline 5 & 26 Mei 2020 & $0 \%$ & Cerah & 3,6 & 3,6 & 2,1 \\
\hline
\end{tabular}




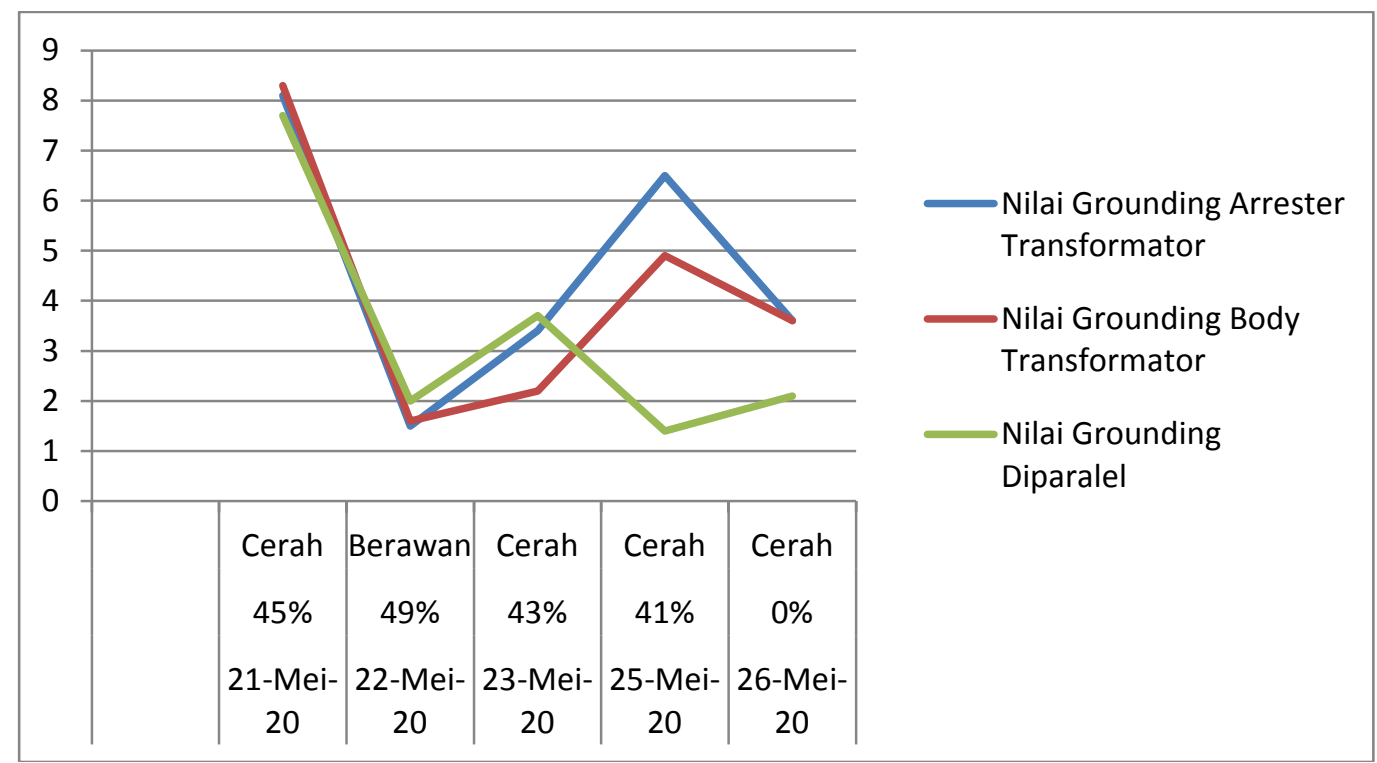

Gambar 8. Grafik Pengukuran Resistansi Pentanahan pada Pukul 14.00 - 15.00 Wib

Dilihat dari gambar 8. Grafik Pengukuran resistansi pentanahan yang dilakukan pada tanggal 21 Mei 2020 yang dilakukan pukul 14.00 sampai dengan pukul 15.00 Wib dapat dilihat pada Tabel 3, menunjukan resistansi tertinggi pada masing-masing pentanahan dimana pada pentanahan Arrester untuk Transformator sebesar 8,1 $\Omega$ di tanggal 21 mei 2020 dan pada pentanahan Body Transformator sebesar 8,3 $\Omega$ di tanggal 21 Mei 2020, dengan keadaan cuaca pada siang hari cerah. Pada pengukuran paralel anatara Grounding Arrester dan Grounding Bodi Transformator nilai resistansi pentanahan tertinggi yaitu 7,7 $\Omega$ pada tanggal 21 Mei 2020. Dilihat dari keadaan cuaca naiknya nilai resistansi pentanahan dipengaruhi oleh keadaan suhu dan kondisi cuaca. Sehingga nilai resistansi pengukuran pentanahan dilapangan lebih besar dari nilai resitansi pentanahan yang didapat dari perhitungan sebesar $0,122 \Omega$.

3. Pengukuran Resistansi Pentanahan Pukul 19.00 - 20.00 WIB

Tabel 4. Pengukuran Resistansi Pentanhan pada Pukul 19.00 - 20.00 Wib

\begin{tabular}{|c|c|c|c|c|c|c|}
\hline No & Tanggal & $\begin{array}{c}\text { Pembebanan } \\
\text { Transformator }\end{array}$ & Cuaca & $\begin{array}{c}\text { Nilai } \\
\text { Grounding } \\
\text { Arrester } \\
\text { Transformator }\end{array}$ & $\begin{array}{c}\text { Nilai Grounding } \\
\text { Body } \\
\text { Transformator }\end{array}$ & $\begin{array}{c}\text { Nilai } \\
\text { Grounding } \\
\text { Diparalel }\end{array}$ \\
\hline 1 & 21 Mei 2020 & $54 \%$ & Cerah & 2,5 & 2,2 & 1,9 \\
\hline 2 & 22 Mei 2020 & $54 \%$ & Gerimis & 1,7 & 2 & 2,4 \\
\hline 3 & 23 Mei 2020 & $54 \%$ & Cerah & 5,4 & 6,9 & 5,8 \\
\hline 4 & 25 Mei 2020 & $50 \%$ & Cerah & 3,6 & 3,3 & 1,4 \\
\hline 5 & 26 Mei 2020 & $0 \%$ & Hujan & - & - & - \\
\hline
\end{tabular}




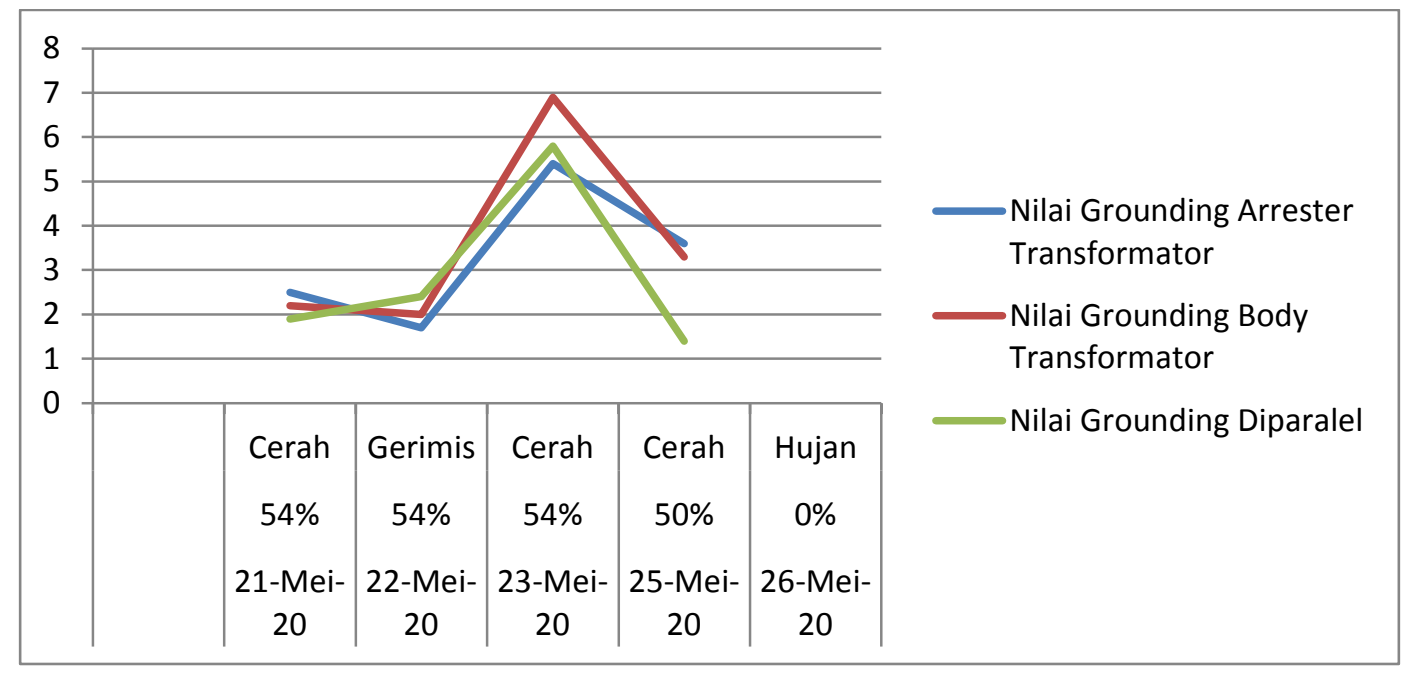

Gambar 9. Grafik Pengukuran Resistansi Pentanahan pada Pukul 19.00 - 20.00 Wib

Dilihat dari gambar 9. Grafik Pengukuran resistansi pentanahan yang dilakukan malam hari pada saat beban puncak dimulai pada tanggal 21 Mei 2020 yang dilakukan pukul 19.00 sampai dengan pukul 20.00 Wib dapat dilihat pada Tabel 4, menunjukan resistansi tertinggi pada masingmasing pentanahan dimana pada pentanahan Arrester untuk Transformator sebesar 5,4 $\Omega$ di tanggal 23 mei 2020 dan pada pentanahan Body Transformator sebesar 6,9 $\Omega$ di tanggal 23 Mei 2020, dengan keadaan cuaca pada malam hari cerah. Pada pengukuran paralel anatara Grounding Arrester dan Grounding Bodi Transformator nilai resistansi pentanahan tertinggi yaitu 5,8 $\Omega$ pada tanggal 23 Mei 2020. Dilihat dari keadaan cuaca naiknya nilai resistansi pentanahan dipengaruhi oleh keadaan suhu dan kondisi cuaca. Sehingga nilai resistansi pengukuran pentanahan dilapangan lebih besar dari nilai resitansi pentanahan yang didapat dari perhitungan sebesar $0,122 \Omega$. Selain berpengaruhnya cuaca pengaruh pembebanan transformator mencapai $54 \%$.

4. Pengukuran Resistansi Pentanahan Pukul 22.00 - 23.00 WIB

Tabel 5. Pengukuran Resistansi Pentanhan pada Pukul 22.00 - 23.00 Wib

\begin{tabular}{|c|c|c|c|c|c|c|}
\hline No & Tanggal & $\begin{array}{c}\text { Pembebanan } \\
\text { Transformator }\end{array}$ & Cuaca & $\begin{array}{c}\text { Nilai } \\
\text { Grounding } \\
\text { Arrester } \\
\text { Transformator }\end{array}$ & $\begin{array}{c}\text { Nilai Grounding } \\
\text { Body } \\
\text { Transformator }\end{array}$ & $\begin{array}{c}\text { Nilai } \\
\text { Grounding } \\
\text { Diparalel }\end{array}$ \\
\hline 1 & 21 Mei 2020 & $51 \%$ & Cerah & 3,5 & 3,1 & 2 \\
\hline 2 & 22 Mei 2020 & $52 \%$ & Cerah & 2,7 & 3,4 & 1,5 \\
\hline 3 & 23 Mei 2020 & $55 \%$ & Cerah & 1,3 & 1,8 & 1,6 \\
\hline 4 & 25 Mei 2020 & $47 \%$ & Cerah & 3,5 & 2,1 & 2,5 \\
\hline 5 & 26 Mei 2020 & $0 \%$ & Gerimis & 3 & 2,8 & 1,6 \\
\hline
\end{tabular}




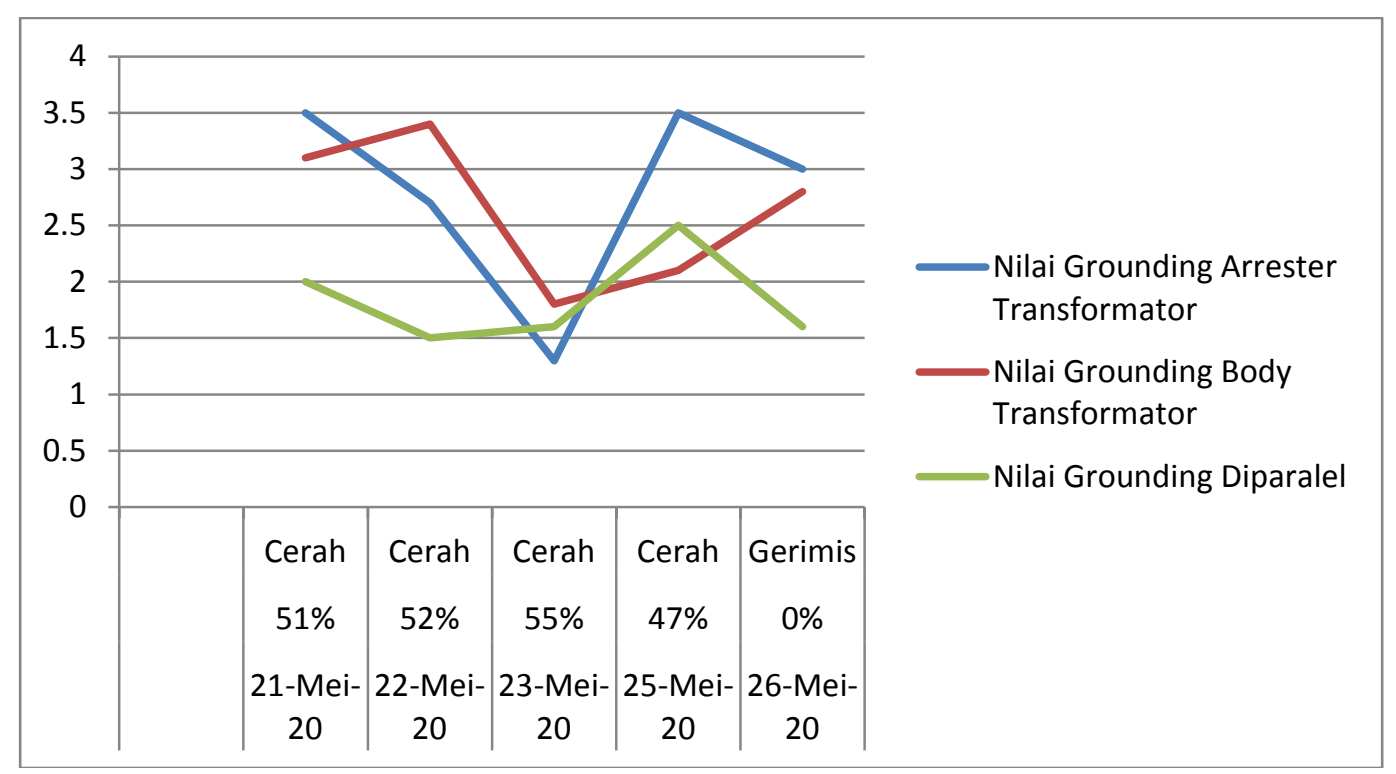

Gambar 10. Grafik Pengukuran Resistansi Pentanahan pada Pukul 22.00 - 23.00 Wib

Dilihat dari gambar 10. Grafik Pengukuran resistansi pentanahan yang dilakukan dini hari atau luar beban puncak dimulai pada tanggal 21 Mei 2020 yang dilakukan pukul 22.00 sampai dengan pukul 23.00 Wib dapat dilihat pada Tabel 5, menunjukan resistansi tertinggi pada masingmasing pentanahan dimana pada pentanahan Arrester untuk Transformator sebesar 3,5 $\Omega$ pada tanggal 21 dan 25 mei 2020 dan pada pentanahan Body Transformator sebesar 3,4 $\Omega$ di tanggal 22 Mei 2020, dengan keadaan cuaca pada malam hari cerah. Pada pengukuran paralel aatara Grounding Arrester dan Grounding Bodi Transformator nilai resistansi pentanahan tertinggi yaitu 2,5 $\Omega$ pada tanggal 25 Mei 2020. Dilihat dari keadaan cuaca naiknya nilai resistansi pentanahan dipengaruhi oleh keadaan suhu dan kondisi cuaca. Sehingga nilai resistansi pengukuran pentanahan dilapangan lebih besar dari nilai resitansi pentanahan yang didapat dari perhitungan sebesar 0,122 $\Omega$.

\section{KESIMPULAN}

Dari hasil penelitian dan pengukuran Instalasi Pentanahan Transformator Distribusi $250 \mathrm{kVA}$ Gardu BA 003 PT. PLN (Persero) UP3 Bengkulu ULP Teluk Segara dapat disimpulkan :

1. Beban puncak terjadi pada malam hari dengan pembebanan mencapai $54 \%$ dari kapasitas transformator distribusi $250 \mathrm{KVA}$ sebesar $194 \mathrm{KVA}$.

2. Resistansi terbesar pada pentanahan Arrester Transformator sebesar $8,1 \Omega$ tejadi pada pukul $14.00-15.00 \mathrm{Wib}$.

3. Resistansi terbesar pada pentanahan Bodi atau Cangkang Transformator sebesar $8,3 \Omega$ terjadi pada pukul $14.00-15.00 \mathrm{Wib}$.

4. Dari pengukuran Paralel Instalasi pentanahan Arrester Transformator dan Bodi atau Cangkang Transformator sebesar 7,7 $\Omega$ pada pukul $14.00-15.00 \mathrm{Wib}$, dengan kondisi cuaca pada siang hari Cerah.

5. Pengaruh cuaca terhadap kenaikan nilai resistansi pentanahan sangat berpengaruh terutama pada saat siang hari antara pukul 14.00 sampai $15.00 \mathrm{Wib}$.

6. Dari hasil perhitungan paralel pentanahan Bodi atau Cangkang Transformator dapat mempekecil resistansi pentanahan sebesar $0,122 \Omega$ dan hasil pengukuran terbesar $7,7 \Omega$ dengan selisih resistansi pentanahan sebesar 7,58 $\Omega$. 


\section{DAFTAR PUSTAKA}

1. AS Pabla, A. H. (2019). Sistem Distribusi Daya Listrik. Jakarta: Erlangga.

2. Daryanto. (2012). Teknik Listrik Lanjutan. Bandung: Satu Nusa.

3. Dian Eka Putra, F. A. (2018). Studi Sistem Pentanahan Saluran Udara Tegangan Tinggi (SUTT) Penghantar 150 KVA Lubuk Linggau - Pekalongan PT.PLN (Persero) Unit Pembangkit dan Transmisi (UPT) Bengkulu. Jurnal Surya Energy, 220-227.

4. Dian Eka Putra, J. U. (2018). Pengukuran Grounding SIIP Panel Distribusi Instalasi Rekam Medis RSUP DR. Mohammad Hoesin Palembang. Jurnal AMPERE, 128-139.

5. Hutahuruk, T. (1999). Pengentanahan Netral Sistem Tenaga dan Pengentanahan Peralatan. Jakarta: Erlangga.

6. PLN. (1978). SPLN1978. Jakarta: PT.PLN.

7. PUIL2000, S. 0.-0.-2. (2000). PUIL2000. Jakarta: Yayasan PUIL .

8. Reynaldo Zoro, W. A. (2018). Sistem Proteksi Petir Pada Sistem Tenaga Listrik. Bandung: Remaja Rosdakarya.

9. Samaulah, H. (2004). Dasar-Dasar Sistem Proteksi Tenaga Listrik. Palembang: Universitas Sriwijaya.

10. Sunarno. (2006). Mekanikal Elektrikal. Yogyakarta: ANDI. 